\title{
EFEITO DA ADIÇÃO DE INIBIDOR DE PROTEINASES (ÁCIDO IODOACÉTICO) SOBRE A ESTABILIDADE DE AMILASES DE Acanthoscelides obtectus
}

\author{
VAREA-PEREIRA, $\mathrm{G}^{2}$ \\ SOARES, M. C. \\ MIYAGUI, D.T.2
}

\begin{abstract}
VARÉA-PEREIRA, G.; SOARES, M. C.; MIYAGUI, D.T. Efeito da adição de inibidor de proteinases (ácido iodoacético) sobre a estabilidade de amilases de Acanthoscelides obtectus. Semina: Ci. Biol. Saúde, Londrina, v. 20/21, n. 2, p. 45-48, jun. 1999/2000.
\end{abstract}

\begin{abstract}
RESUMO: O estudo das características estruturais e cinéticas das amilases presentes no trato digestivo de lanvas de insetos que afetam a produção agricola de alimentos deve ser realizado em enzimas purificadas. No processo de purificação das amilases, os rendimentos tem sido prejudicados por fatores como a atividade de proteinases. Para estudar o efeito da adição de inibidores de proteinases sobre a estabilidade de amilases, larvas inteiras de Acanthoscelides obtectus foram trituradas em solução $\mathrm{NaCl} 0,85 \%$ contendo 3,10 e $15 \mathrm{mM}$ de ácido iodoacético. Os extratos obtidos foram ensaiados quanto a atividade proteinásica e amilásica durante 48 horas a $4^{\circ} \mathrm{C}$. Os resultados mostraram que a adição de $3 \mathrm{mM}$ de AlA reduziu em $50 \%$ a atividade de proteinases, sem alterar significativamente a atividade de amilases durante 24 horas. O emprego de concentrações de 10 e $15 \mathrm{mM}$ de ácido iodoacético reduziram a atividade proteinásica em $70 \%$, e diminuiram também a atividade de amilases em torno de 80 e $95 \%$, respectivamente. Os resultados sugerem que, se tais condições forem consideradas, é possivel obter maior recuperação da atividade em procedimentos de purificação de amilases de insetos.
\end{abstract}

PALAVRAS-CHAVE: Amilase; proteinase; Acanthoscelides obtectus; inibidor de proteinase.

\section{INTRODUÇÃO}

A produção agrícola de leguminosas sofre sérios prejuízos devido à infestação das sementes por Acanthoscelides obtectus (Ordem: COLEOPTERA, Subordem: POLIPHAGA, Familia: BRUCHIDAE). Conhecidos como "carunchos de feijão", estes insetos afetam a qualidade do produto destinado ao consumo direto e à semeadura, pois durante o ataque o embrião é destruido juntamente com o endosperma da semente (Gallo et al., 1988).

A capacidade de infestação e o desenvolvimento dos insetos pode ser influenciada pelos nutrientes constituintes das sementes (Parra, 1991) e pela atividade de enzimas digestivas (Terra, 1988), como as amilases responsáveis pela liberação de energia para o trabalho celular.

Amilases de larvas de $A$. obtectus apresentaram menor atividade quando comparadas com outras espécies de insetos criados em cereais (Gutierrez et al., 1990) e acentuada perda de atividade amilásica em procedimentos de purificação por cromatografia em gel Sephadex G-100 (Miyagui, 1993) e complexação com glicogênio (Varéa-Pereira, 1999). Tais perdas de atividade amilásica podem estar relacionadas com a atividade de cisteíno-proteinases (Murdok et al., 1988; Lemos et al., 1990; Hines et al., 1992) e/ou aspartato-proteinases (Silva e XavierFilho, 1991) também presentes em extratos de larvas de bruquídeos. Estes fatos tem dificultado a realização de estudos sobre as características estruturais e cinéticas das amilases, e a conseqüente elaboração de propostas para redução de sua atividade "in vivo", colaborando com o controle do desenvolvimento e infestação de insetos.

Desta forma, o presente trabalho teve o objetivo de estudar a influência da adição de diferentes concentrações do inibidor ácido iodoacético (AIA) sobre a atividade de proteinases, visando a manutenção da atividade durante $o$ isolamento $e$ armazenamento de amilases do trato digestivo de larvas de $A$. obtectus.

\footnotetext{
${ }^{1}$ Aluna do Curso de Especialização em Bioquímica Aplicada

2 Docentes do Departamento de Bioquímica, Centro de Ciências Exatas, Universidade Estadual de Londrina, Caixa Postal 6001 , Londrina/Pr, CEP $86051-990$
} 


\section{MATERIAL E MÉTODOS}

\section{Obtenção de larvas de $A$. obtectus}

Larvas de $A$. obtectus foram criadas em câmara sem iluminação, à temperatura $25 \pm 2^{\circ} \mathrm{C}$ e umidade relativa de $70 \pm 10 \%$, empregando-se 100 insetos de mesma geração para cada 20 gramas de feijão comum (Phaseolus vulgaris). As larvas foram retiradas dos feijões através da separação e quebra dos cotilédones da semente.

\section{Extração das enzimas}

Foram extraídas enzimas de 800 larvas inteiras de $A$. obtectus divididas em quatro grupos através de trituração em solução de $\mathrm{NaCl} 0,85 \%$ contendo 3 , 10 e $15 \mathrm{mM}$ de ácido iodoacético - AlA (Fluka). O volume dos sobrenadantes obtidos da centrifugação a $3.530 \times$ g durante 15 minutos foram completados para $10 \mathrm{~mL}$ e armazenados a $4^{\circ} \mathrm{C}$ durante 48 horas. Um dos grupos de larvas foi triturado sem adição de AIA e considerado grupo padrão.

\section{Determinação da atividade amilásica}

A atividade das amilases de larvas de $A$. obtectus foi determinada conforme descrito por Bernfeld (1955) com modificações sugeridas por Miyagui (1993). Alíquotas de $50 \mathrm{~mL}$ de amostra adequadamente diluídas, foram adicionadas a $450 \mathrm{~mL}$ de solução tampão acetato de sódio $100 \mathrm{mM} \mathrm{pH} \mathrm{5,4} \mathrm{contendo}$ $38 \mathrm{mM}$ de cloreto de sódio $(\mathrm{NaCl})$ e $0,1 \mathrm{mM}$ de cloreto de cálcio $\left(\mathrm{CaCl}_{2}\right)$ e $500 \mathrm{~mL}$ de solução de amido a $1 \%$ reduzido com borohidreto de sódio como substrato (Strumeyer, 1967), à temperatura de $37^{\circ} \mathrm{C}$. Após 5 minutos, a reação foi interrompida pela adição de $1 \mathrm{ml}$ do reagente ácido 3,5-dinitrosalicilico (DNS) e aquecida em banho-maria fervente por 10 minutos. Após completar o volume da reação para $5 \mathrm{ml}$, os açúcares redutores formados pela ação das amilases foram quantificados através da leitura da absorbância em 540 nm (espectrofotômetro Femto 482 UV/VIS) utilizando solução padrão de maltose $1 \mathrm{mg} / \mathrm{mL}$. Os resultados foram expressos em Unidades de Amilase (AU). Uma AU foi definida como a quantidade de enzimas que produz $1 \mathrm{mg}$ de maltose por $\mathrm{mL}$ de extrato por minuto nas condições da reação.

\section{Determinação da atividade proteinásica}

A atividade proteinásica foi determinada de acordo com Lemos et al. (1990), pelo emprego de azocaseína como substrato. A reação foi iniciada pela adição de alíquotas de $500 \mathrm{~mL}$ de extrato enzimático a $500 \mathrm{~mL}$ de solução de azocaseína 5 $\mathrm{mg} / \mathrm{mL}$ preparada em tampão acetato $100 \mathrm{mM} \mathrm{pH}$ 5,4 a $37^{\circ} \mathrm{C}$ por 45 minutos, e interrompida pela adição de $500 \mathrm{~mL}$ de ácido tricloroacético (TCA) $10 \%$ gelado e centrifugada a $1.100 \times \mathrm{g}$ por 15 minutos. Ao sobrenadante adicionou-se igual volume de $\mathrm{KOH} 5 \mathrm{~N}$. A absorbância foi obtida em $428 \mathrm{~nm}$ empregando como branco uma reação na qual o TCA $10 \%$ foi adicionado ao meio antes da adição do substrato.

\section{Determinação de proteínas}

O teor de proteínas dos extratos enzimáticos foi determinado logo após a centrifugação pelo método descrito por Hartree (1972), utilizando solução padrão de albumina de soro bovino $1 \mathrm{mg} / \mathrm{mL}$.

\section{Efeito do AIA sobre a atividade das enzimas}

O efeito da adição de 3, 10 e $15 \mathrm{mM}$ de AIA sobre a estabilidade de enzimas de extratos de larvas de $A$. obtectus mantidos a $4^{\circ} \mathrm{C}$, foi obtido através da determinação das atividades amilásica e proteinásica em diferentes tempos durante um período de 48 horas.

\section{RESULTADOSE DISCUSSÃO}

\section{Obtenção de larvas de $A$. obtectus}

As criações de A. obtectus forneceram grande número de larvas após 23 dias de desenvolvimento, demonstrando boa adaptação às condições experimentais como temperatura e umidade empregadas. Miyagui (1993) e Varéa-Pereira (1999) também obtiveram tempos de desenvolvimento de larvas de A. obtectus igual a 23 dias.

Durante a retirada das larvas dos cotilédones das sementes de feijão, observou-se variabilidade dos graus de infestação e maior preferência pelos grãos dispostos no fundo do recipiente de criação.

\section{Determinação de proteinas}

A adição de AlA não interferiu no teor de proteinas durante a obtenção dos extratos enzimáticos, cujos valores foram semelhantes entre si e iguais a 0,726 , $0,782,0,704$ e $0,714 \mathrm{mg} / \mathrm{mL}$, para o extrato padrão e para os extratos com 3, 10 e $15 \mathrm{mM}$ de AIA, respectivamente.

\section{Efeito do AIA sobre a atividade das enzimas}

A Figura 1 mostra o efeito de diferentes concentrações de AlA sobre as atividades 
proteinásica e amilásica de extratos de larvas de A.obtectus mantidos a $4^{\mathrm{a}} \mathrm{C}$ durante 48 horas. $\mathrm{A}$ adição de 3,10 e $15 \mathrm{mM}$ de AlA reduziu significativamente a atividade de proteinases nos extratos de larvas de $A$. obtectus quando comparados com o extrato padrão obtido sem adição de inibidor (Figura 1A). As porcentagens de redução média foram estimadas em $50 \%$ para adição de 3 $\mathrm{mM}$ de AIA e $70 \%$ para adição de 10 e $15 \mathrm{mM}$ de AIA. Estes resultados foram comparáveis aos obtidos por Silva \& Xavier-Filho (1991), que obtiveram $58,2 \%$ de inibição de proteinases de larvas de Callosobruchus maculatus através da adição de 3 $\mathrm{mM}$ de ácido iodoacético. Tanto a atividade proteinásica remanescente apresentada pelos extratos contendo AIA, como a elevação desta atividade no extrato padrão verificada após 24 horas a $4^{\circ} \mathrm{C}$, podem estar relacionadas com a ativação de diferentes espécies de endo e exoproteinases, pois, segundo Silva \& Xavier-Filho (1991), AlA inibiu caracteristicamente aspartato-proteinases de tratos digestivos de larvas de Callosobruchus maculatus e Zabrotes subfasciatus. A Figura 1B mostra que os extratos padrão e com $3 \mathrm{mM}$ de AlA apresentaram pequena variação da atividade amilásica até 24 horas. Entretanto, após este periodo, o extrato padrão sofreu acentuada redução da atividade amilásica, provavelmente relacionada com a elevação da atividade proteinásica verificada após este mesmo tempo (Figura 1A). Os extratos padrão e com $3 \mathrm{mM}$ de AIA apresentaram atividade amilásica semelhantes entre si demonstrando que nesta concentração, o inibidor não interferiu na atividade das amilases. Por outro lado, a adição de $10 \mathrm{mM}$ e $15 \mathrm{mM}$ de AIA interferiu significativamente sobre a atividade das amilases ocasionando uma redução média de $80 \%$ e $95 \%$ da atividade amilásica, respectivamente.

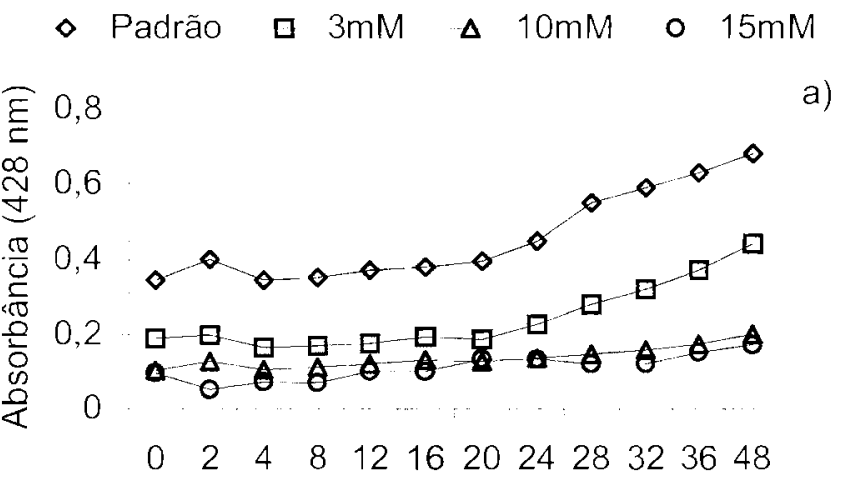

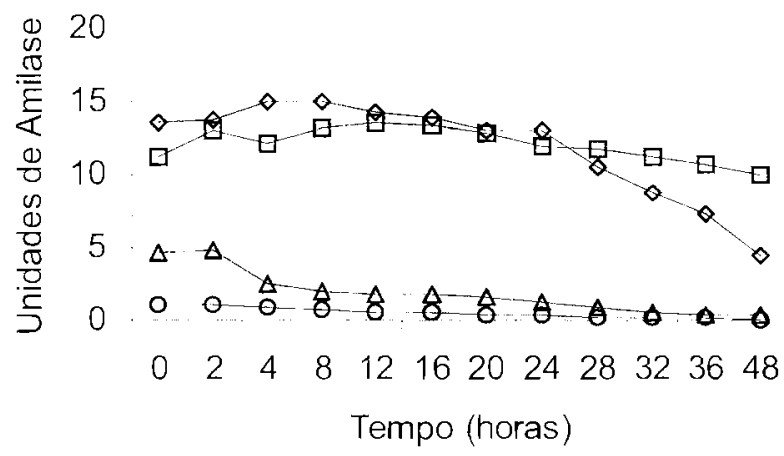

b)

Figura 1 - Efeito do tempo e da adição de 3, 10 e $15 \mathrm{mM}$ de ácido iodoacético sobre as atividades proteinásica (A) e amilásica (B) de extratos enzimáticos de larvas de $A$. obtectus. Extrato padrão sem adição de AIA.

\section{CONCLUSÃO}

Os resultados obtidos neste trabalho demonstraram que a adição de $3 \mathrm{mM}$ de AIA foi suficiente para inibir em torno de $50 \%$ da atividade de proteinases sem afetar significativamente a atividade amilásica, promovendo desta forma, a proteção das amilases presentes nos extratos mantidos a $4^{\circ} \mathrm{C}$ durante 24 horas. Isto sugere que, nestas condições, métodos de purificação de amilases de trato digestivo de larvas de $A$. obtectus poderão ser realizados com boa recuperação da atividade amilásica. 
VARÉA-PEREIRA, G.; SOARES, M. C.; MIYAGUI, D.T. Effect of iodoacetic acid on Acanthoscelides obtectus amylase stability. Semina: Ci. Biol. Saúde, Londrina, v. 20/21, n. 2, p. 45-48, jun. 1999/2000.

ABSTRACT: Research on the amylases from the gut of the insect pest Acanthoscelides obtectus was studied using purified enzymes. The purification procedures resulted in low recoveries of enzyme because of the degradative action of insect-gut proteinases. To study the inhibition effects of proteinases on amylase stability, enzymes of whole larvae homogenates of Acanthoscelides obtectus were extracted with $0.85 \%$ $\mathrm{NaCl}$ solution containing 3,10 and $15 \mathrm{mM}$ of iodoacetic acid. The extracts were assayed for proteinase and amylase activity against the substrates, azocasein and starch, respectively, in $100 \mathrm{mM}$ sodium acetate buffer (pH 5,4) containing $0,1 \mathrm{mM} \mathrm{CaCl}$ and $38 \mathrm{mM} \mathrm{NaCl}$ over a $48 \mathrm{~h}$-period at $4{ }^{\circ} \mathrm{C}$. The result showed that iodoacetic acid at a concentration of $3 \mathrm{mM}$ did not interfere with the amylase activity. However, the proteinase activity was reduced by some $50 \%$ at the same concentration during $24 \mathrm{~h}$. When 10 and $15 \mathrm{mM}$ iodoacetic acid were used, the proteinase activity decreased by $70 \%$, while the amylase activity was reduced by 80 and $95 \%$, respectively.

KEY WORDS: Amylase; proteinase; Acanthoscelides obtectus; proteinase inhibitor.

\section{REFERÊNCIAS BIBLIOGRÁFICAS}

BERNFELD, P. Amylase alpha and beta. Meth. Enzimol. v.1, p. $149-154,1955$

GALLO, D.; NAKANO, O.; SILVEIRA NETO, S.; CARVALHO, R P. L.; BATISTA, G. C.; BERTI-FILHO, E.; PARRA, J. R. P.; ZUCCHI, R. A.; ALVES, S. B.; VENDRAMIM, J. D. Manual de Entomologia Agricola. São Paulo: Agronômica "CERES", 1988. 649p

GUTIERREZ. C.; SANCHEZ-MONGE, R.; GOMEZ, L.; RUIZTAPIADOR, M.: CASTAÑERA, P.; SALCEDO, G. a-Amylase activities of agricultural insect pests are specifically affected by different inhibitor preparations from wheat and barley endosperms. Plant Science, v.72, p.37-44, 1990.

HARTREE, E. F. Determination of protein: A modification of the Lowry method that gives a linear photometric response. Analytical Biochemistry. n. 48, p. 422-427, 1972

HINES, M. E.; OSUALA, C. I.; NIELSEN, S. S. Screening for cysteine proteinase inhibitor activity in legume seeds. $J$. Sci. Food Agric., v. 59, p. 555-557, 1992.

LEMOS, F. J. A.; CAMPOS, F. A. P.; SILVA, C. P.; XAVIERFILHO, J. Proteinases and amylases of larval midgut of Zabrotes subfasciatus reared on cowpea (Vigna unguiculata) seeds. Entomol. Exp. Appl., v. 56, p. 219227, 1990

MIYAGUI, D. T. Efeito dos inibidores de amilases do feijão e do alpiste sobre os bruquideos. São Paulo, 1993. Tese (Doutorado) - FCF-USP. $89 \mathrm{p}$.

MURDOCK, L. L.; SHADE, R. E.; POMEROY, M. A. Effects of E64 , a cysteine proteinase inhibitor, on cowpea weevil growth, development, and fecundity. Environmental Entomology. v. 17, n. 3, p. 467-469, 1988.

PARRA, I. R. P. Consumo e utilização de alimentos por insetos p.9-66. In: PANIZZI, A. R. E.; PARRA, I. R. P. Ecologia Nutricional de Insetos e Suas Aplicações no Manejo de Pragas. [S.I] Manole, 1991. 359p.

SILVA, C. P.; XAVIER-FILHO, J. Comparison between the levels of aspartic and cysteine proteinases of the larval midguts of Callosobruchus maculatus (F.) and Zabrotes subfasciatus (BOH.) (COLEOPTERA BRUCHIDAE). Comp. Biochem. Physiol. v. 99B, n. 3 p. 529-533, 1991.

STRUMEYER, D. H. A modified starch for use in amylase assays. Analytical Biochemistry. v. 19, p. 61-71, 1967.

TERRA, E. R. Physiology and biochemistry of insect digestion an evolutionary perspective. Brazilian J. Med. Biol. Res. v.21, p.675-734, 1988

VARÉA-PEREIRA, G. Atividade de inibidores de a-amilases do triticale parcialmente purificados sobre amilases de Acanthoscelides obtectus e Tenebrio molitor. São Paulo, 1999. Tese (Doutorado) - FCF-USP. 147 fls. 